\title{
主幹動脈閉塞を伴う破裂脳動脈瘤症例の外科的治療
}

\author{
川村 伸悟·佐山 一郎 鈴木 明文·大田 英則·根本 正史 山田 武 \\ 安井 信之
}

\section{Surgical Treatment of Patients with Aneurysmal Subarachnoid Hemorrhage associated with Main Artery Occlusion}

\author{
Shingo Kawamura, Ichiro Sayama, Akifumi Suzuki, Hidenori OHTA, \\ Masahito Nemoto, Takeshi YamadA and Nobuyuki YASUI \\ Department of Surgical Neurology, Research Institute for Brain and Blood Vessels-Akita, Akita
}

\begin{abstract}
The purpose of this paper is to elucidate suitable surgical treatments in patients with aneurysmal subarachnoid hemorrhage (SAH) associated with main artery occlusion. The subjects were nine SAH patients with main artery occlusion (mean age, 53 years). The sites of their occlusions are as follows: internal carotid artery in five; middle cerebral artery (horizontal portion) in three; common carotid artery in one. None of the patients had had cerebral ischemia previously. Surgical results were evaluated at the time of hospital discharge, and were compared with a follow-up study.

Of the four patients who fully recovered, three had been operated on within 48 hours of the onset of SAH, and one underwent bypass surgery following the aneurysmal surgery. Another had symptoms of cerebral vasospasm (VS) 14 days after the SAH in the contralateral hemisphere, but the symptoms disappeared within 1 week and the aneurysm was operated on 21 days later. Among these four patients, the preoperative consciousness level was "alert" in three and "stuporous" in one. Postoperatively, four of the other five patients were partially or fully dependent, and one died. Four were operated on from 9 to 26 days after the SAH, and one underwent surgery 38 hours after the SAH. The preoperative consciousness level of this group was "alert" in three, "drowsy" in one, and "semicomatose" in one. In all five of these patients the main cause of the poor outcome was symptomatic VS, the symptoms of which appeared from 3 to 11 days after the SAH. Four patients had poor collateral circulation, as demonstrated angiographically from 6 to 12 days after the $\mathrm{SAH}$. It is worth noting that a severe neurological deficit developed when a previously asymptomatic arterial occlusion became symptomatic following the occurrence of VS. In conclusion, a bypass procedure following surgery for an aneurysm should be performed within 2 to 3 days after the SAH in the interest of preventing the development of VS-induced cerebral ischemia in the hemisphere in which the arterial occlusion is present.
\end{abstract}

Key words: cerebral aneurysm, subarachnoid hemorrhage, arterial vasospasm, arterial occlusion, EC/IC bypass

秋田県立脳血管研究センター脳神経外科

Address reprint requests to: S. Kawamura, M.D., Department of Surgical Neurology, Research Institute for Brain and Blood Vessels-Akita, 610 Senshu-kubota-machi, Akita 010.

受稿 1986年6月26日受理 1987年 9 月14日 


\section{I はじめに}

破裂脳動脈瘤 (AN) 症例に主幹動脈閉塞を伴 5 場合に は，脳血管攣縮(VS)などに起因する側副血行の障害が， 潜在していた脳虚血を顕在化せしめることで神経症状をよ り出現させやすいと考えられ，不良な転帰をとる場合も少 なくない10,15)，したがって，このよらな症例で良好な予後 を期待するためには，治療上，特別の配虑が必要と思われ る。また，ANの增大拈よび破裂に影響する因子として hemodynamic stress の関与が指摘されているが，このよう な症例で主幹動脈の閉塞により生じた特異な血行動態を検 討することで，この点についても示唆が得られると考えら れる。そこで，著者らの施設で経験した AN 破裂前より 主幹動脈閉塞を伴う10症例のなかで，AN 根治術を施行し えた 9 例の手術成績を検討し，本症の妥当な治療法につき 報告するとともに，ANの增大，破裂に及ぼす血行動態の 影響についても考察を加えて報告する.

\section{II 対象および方法}

対象は，秋田県立脳血管研究センターにて1969年から 1986年 3 月までの間に入院加療を行った AN 症例のなか で,AN の破裂以前より主幹動脈の閉塞を有し, 破裂 AN に対して根治術が施行された 9 例，男性 8 例，女性 1 例 で，年柃は38〜68才(平均53才)である(Table 1)。たたし， 〈症例 5〉は AN 根治術および外減王術を他院で施行された が，術前の脳血管撮影で左内頸動脈 (IC) 閉塞が確認され ていた． 9 例の発症様式は，䯣膜刺激症状など，典型的な クモ膜下出血(SAH)のそれである．全例で脳虚血発作の 既往はなかった。SAH 最終発作から AN 根治術までの経 過時間は，〈症例 1〜5〉では 9 35日，〈症例 6〜9〉では 9 時間〜2 日であった，術前意識レベルは，清明 6 例，傾 眠・昏迷・半昏睡各 1 例であった。

当院にCT が導入される以前の〈症例 1〉を除き，CTは 入院時に行って，その後毛経時的に follow した．当院で 施行した脳血管撮影の内訳は，全例で両側頸動脈撮影およ び少なくとも一側の椎骨動脈撮影を術前あるいは術後に施 行し, 症例によってはVSの経過の follow のために追加検 査も行った。そしてこれらの脳血管撮影所見を基にし て, VSの認められる範囲および閉塞血管より末梢部の頭 蓋内側副血行を評価した。このとき，VSを一側IC 系に 認める場合を“和all”VS，両側IC系に認める場合を “diffuse”VS と判定した。 また，側副血行の評価では，閉 塞血管より末梢部全域が描出される場合に“good”，側副 血行の不良な領域を認める場合に“poor”とした。ただ し，髄膜刺激症状を除いた他の神経症状がない場合には，
側副血行を評価する上で必要十分な脳血管撮影が施行され ていなくとも，側副血行は“good”と判断したＶVSによ る神経学的徵候の判定基準は，急激に新なな局所神経症状 が出現した場合，または既存の局所神経症状が急激に悪化 した場合で，脳血管撮影でその症状を説明できる部位に VSが確認され，原則としてCTによりVS 以外の神経症 状出現の原因を否定できる場合とした．

${ }^{133} \mathrm{Xe}$ 吸入法による局所脑血流量 $(\mathrm{CBF})$ の検討は，〈症例 5，6，8>の 3 症例に行った。測定は Novo Cerebrograph IRCBF-32B (Novo Diagnostic System, Denmark)を用いた 吸入法( 症例 5〉) および Valmet rCBF Analizer BI-1400 (Valmet Oy Instrument Works, Finland)を用いた静注法 (〈症例 6,8〉)にて行い, initial slope index (ISI) に上る半球 平均血流量で検討した。当院におけるISIの正常範团 (土2 SD) は，それぞれ38〜65（Xe吸入法）蛒よび40〜65 (Xe 静注法) $\mathrm{m} l / 100 \mathrm{~g} / \mathrm{min}$ である。

手術成績は退院時の転帰で評価した。転懵は，全快，な んらかの神経症状残すを日常生活に介助不要，一部要介 助, 全介助, 死亡の 5 段階評価とした。 また，9例中 6 例 では電話による退院後の follow を行った．Follow-up 期間 は 5 力月 7 年(平均2.6年)であった，そして，各症例ご とに転帰を左右した因子についてる検討した。

\section{III 症 例}

代表例を提示する.

<症例 $7>52$ 才, 男性

発症38時間後に意識清明の状態で，破裂右 IC AN の根 治術のみを施行した。術前のCTでは両側性に diffuseな SAHを認め(Fig. 1A)，脳血管撮影では右 IC AN の注か に約 $50 \%$ の右中大脳動脈 $(\mathrm{MC})$ 主幹部狭窄, 左 $\mathrm{MC}$ 水平部 $\left(\mathrm{M}_{1}\right)$ 閉塞を認め, 左 $\mathrm{MC}$ 域は主に前大脳動脈を介する側 副血行により血流を受けていた(Fig. 2A). Day 4 に急速 に意識障害が進行し，CT上脳浮腫の增強を認め(Fig 1B)，減圧のために腫大した側頭筋を切除し，外減圧術を 追加した，その後意識の改善をみたが， day 7 に意識障害 が進行し, 右片麻疩も出現, day 11 亿施行したCT上では 低吸収域が左側頭頭頂部, 両側傍側脳室前部白質に出現し た(Fig. 1C)。この症例は, 右片麻舫, 全失語を後遗し, 発症 2 年後の現在, 全介助の状態である. バイパス術が施 行されずにVS出現時期に MC 閉塞側の脳梗塞を生した 症例である(Fig. 2B).

<症例 8> 43才, 男性

発症 9 時間後に意識清明の状態で, 破裂左 IC AN およ び非破裂前交通動脈( ACo) AN の根治術とともに右浅側頭 動脈一中大脳動脈(ST-MC) ヘイイパスを施行した。CTで 
Table 1 Clinical summary of nine patients with ruptured aneurysm associated with occlusion of a major cerebral artery

\begin{tabular}{|c|c|c|c|c|c|c|c|c|c|}
\hline $\begin{array}{l}\text { Case No. } \\
\text { and Year } \\
\text { (Age, Sex) }\end{array}$ & History of CVD & $\begin{array}{l}\text { Signs/ } \\
\text { symptoms } \\
\text { at onset }\end{array}$ & $\begin{array}{c}\text { Site of } \\
\text { aneurysm }\end{array}$ & $\begin{array}{l}\text { Site of } \\
\text { occlusion }\end{array}$ & $\begin{array}{l}\text { Main } \\
\text { collateral } \\
\text { route }\end{array}$ & $\begin{array}{l}\text { Preopera- } \\
\text { tive cons. } \\
\text { level }\end{array}$ & $\begin{array}{c}\text { Surgery } \\
\text { for } \\
\text { aneurysm }\end{array}$ & $\begin{array}{l}\text { External } \\
\text { decom- } \\
\text { pression }\end{array}$ & $\begin{array}{l}\text { ST-MC } \\
\text { bypass }\end{array}$ \\
\hline $\begin{array}{l}1 \\
(52, \mathrm{M})\end{array}$ & no & $\mathrm{SAH}$ & $\mathrm{ACo}^{* *}$ & rt. IC & $\begin{array}{l}\text { It. IC } \\
\rightarrow \text { ACo }\end{array}$ & $\begin{array}{l}\text { semicoma- } \\
\text { tose }\end{array}$ & 9 days & $\underset{(1 \mathrm{t} . \rightarrow \mathrm{rt} .)}{\text { bil. }}$ & yes \\
\hline $\begin{array}{l}2 \quad 1978 \\
(68, M)\end{array}$ & no & SAH & rt. IC-PCo ${ }^{* * *}$ & lt. $\begin{array}{l}M C \\
\left(M_{1}\right)\end{array}$ & $\begin{array}{l}\text { lt. IC } \\
\rightarrow \text { moyamoya } \\
\text { vessels; } \\
\text { VB } \rightarrow \text { lt. PC }\end{array}$ & clear & 35 days & no & no \\
\hline $\begin{array}{l}3 \quad 1978 \\
(57, \mathrm{M})\end{array}$ & no & $\begin{array}{l}\text { SAH, } \\
\text { lt. lower } \\
\text { limb } \\
\text { paresis }\end{array}$ & $\begin{array}{l}\mathrm{ACo}^{* *}, \\
\mathrm{ACo}\end{array}$ & rt. IC & $\begin{array}{l}\text { lt. IC } \rightarrow \text { ACo } \\
(\rightarrow \text { rt. AC); } \\
\text { rt. IC } \rightarrow \text { rt. PCo } \\
\rightarrow \text { rt. PC } \\
(\rightarrow \text { rt. MC })\end{array}$ & clear & 22 days & no & $\begin{array}{l}\text { yes } \\
\text { (rt.) }\end{array}$ \\
\hline $\begin{array}{l}4 \quad 1978 \\
(63, M)\end{array}$ & no & SAH & $\begin{array}{l}\text { rt. PG-PCo }{ }^{* *} \text {, } \\
\text { rt. IC-PCo }\end{array}$ & rt. IC & $\mathrm{VB} \rightarrow \mathrm{rt} . \mathrm{PCo}$ & drowsy & 10 days & no & $\begin{array}{l}\text { yes } \\
\text { (rt.) }\end{array}$ \\
\hline $\begin{array}{l}51982 \\
(38, M)\end{array}$ & no & SAH & $\begin{array}{l}\text { ACo, } \\
\text { lt. PC-PCo }\end{array}$ & It. IC & $\begin{array}{l}\text { rt. IC } \rightarrow \text { ACo } \\
(\rightarrow \text { lt. AC) } \\
\text { VB } \rightarrow \text { It. PCio } \\
(\rightarrow \text { lt. MC })\end{array}$ & clear & 26 days & yes (lt.) & no \\
\hline $\begin{array}{l}6 \quad 1983 \\
(41, F)\end{array}$ & no & $\begin{array}{l}\text { SAH, } \\
\text { rt. Barre's } \\
\text { arm sign }\end{array}$ & lt. IC-PCo ${ }^{* *}$ & lt. $\begin{array}{l}\mathrm{MC} \\
\left(\mathrm{M}_{1}\right)\end{array}$ & $\begin{array}{l}\text { It. accessory } \\
\text { MC } \\
\rightarrow \text { moyamoya } \\
\text { vessels }\end{array}$ & clear & 25 hours & no & no \\
\hline $\begin{array}{l}7 \quad 1983 \\
(52, M)\end{array}$ & no & SAH & $\begin{array}{l}\text { rt. IC-PCo**, } \\
\text { rt. IC-ACh, } \\
\text { lt. PICA\# }\end{array}$ & It. $\underset{\left(M_{1}\right)}{M C}$ & It. IC $\rightarrow$ It. AC & clear & 38 hours & yes (rt.) & no \\
\hline $\begin{array}{l}81985 \\
(43, M)\end{array}$ & no & SAH & $\begin{array}{l}\text { lt. IC-ACh }{ }^{* *} \text {, } \\
\text { ACo }\end{array}$ & rt. IC & It. $\mathrm{IC} \rightarrow \mathrm{ACo}$ & clear & 9 hours & no & $\begin{array}{l}\text { yes } \\
\text { rt. })\end{array}$ \\
\hline $\begin{array}{l}9 \\
(59, \mathbf{M})\end{array}$ & $\begin{array}{l}\text { SAH: rt. IC (CP) } \\
\text { aneurysm } \\
\rightarrow \text { rt. CC ligation } \\
\quad \text { (in 1975) }\end{array}$ & SAH & $\begin{array}{l}\mathrm{ACo}^{* *} \\
\text { rt. IC (CP) \# }\end{array}$ & rt. CC & $\begin{array}{l}\text { It. IC } \rightarrow \text { ACo } \\
(\rightarrow \text { rt. AC); } \\
\text { rt. subclavian } \\
\quad \text { artery } \\
\rightarrow \text { rt. EC } \\
\rightarrow \text { rt. IC } \\
(\rightarrow \text { rt. MC })\end{array}$ & stuporous & 2 days & no & no \\
\hline
\end{tabular}

In Case 3, the right IC was occluded just distal to the right $\mathrm{ACh}$. In Case 5, surgery and external decompression were performed in another hospital, and accurate information about the rupture site was not obtained. In Cases 7 and 9, direct surgery for the aneurysm (\#) was not performed. "Interval from last attack of SAH; ${ }^{* *}$ rupture site. AC indicates anterior cerebral artery; ACh, anterior choroidal artery; $\mathrm{ACo}$, anterior communicating artery; $\mathrm{CC}$, common carotid artery; cons., consciousness; $\mathrm{CP}$, cavernous portion; CVD, cerebrovascular disease; EC, external carotid artery; IC, internal carotid artery; $\mathrm{MC}$, middle cerebral artery; $\mathrm{M}_{1}$, horizontal portion of $\mathrm{MC}$; $\mathrm{PC}$, posterior cerebral artery; PCo, posterior communicating artery; PICA, posterior inferior cerebellar artery; SAH, subarachnoid hemorrhage; ST, superficial temporal artery; VB, vertebro-basilar system.

は両側性に diffuseなSAHを認め,脳血管撮影では左 IC AN, ACo ANのほかに，右 IC 起始部完全閉塞とACoを 介しての良好な側副血行がみられた(Fig. 3A)。本例では SAH 後 7 日目に左 IC 扰よび左 $\mathrm{M}_{1}$ に focal VS 認めた が，VSによる神経崲候は認めなかった。また，ACoを介 する右 MC 領域への cross filling が著明に減少したが，こ れは吻合された右 STが術前に比べ著明に拡張し，バイパ スを介して右 MC 全域が血液供給されたためである(Fig. 3B).この症例ではVSによる閉塞側半球の脳虚血が心配 されたが，バイパスからの血流が良好であり，神経症状の 出現もみず，完全に回復した(Fig. 3C).
<症例 $4>63$ 才, 男性

発症 7 日目に傾眠状態で入院、入院時の脳血管撮影で右 IC は cavernous portionにて完全に閉塞しており，破裂右 後大脳動脈一後交通動脈 (PC-PCo) 分岐部 AN および非破 裂右 IC ANを認め，右 MCには中等度のVSを認めた。 発症10日目に ANの根治術と右 ST-MCバイパスを施行 した. 術後脳浮腫が増強, 出血性梗塞も合併し, 発症12目 目に減王術を施行するも意識障害が僄延，左片麻疩も残 し，全介助の状態で退院した，この症例は入院時期が漣 く, 手術を発症10日目のVS出現時期に行っており, 手術 侵襲とバイパスを介した血流の増加が出血性梗塞を引き起 
Table 1 (continued)

\begin{tabular}{|c|c|c|c|}
\hline $\begin{array}{l}\text { Angio- } \\
\text { graphy* }\end{array}$ & Vasospasm & $\begin{array}{l}\text { Collateral } \\
\text { circulation }\end{array}$ & $\begin{array}{l}\text { Symptoms of } \\
\text { vasospasm }\left({ }^{*}\right)\end{array}$ \\
\hline $\begin{array}{l}6 \text { days } \\
9 \text { days } \\
10 \text { days }\end{array}$ & $\begin{array}{l}\text { diffuse } \\
\text { diffuse }^{+} \\
\text {diffuse }^{+}\end{array}$ & $\begin{array}{l}\text { poor } \\
\text { poor } \\
\text { poor }^{\top}\end{array}$ & $\begin{array}{l}\text { rt. hemiparesis ( } 3 \text { days); } \\
\text { lt. hemiparesis and cons. } \\
\text { deteriorated ( } 5 \text { days) }\end{array}$ \\
\hline $\begin{array}{l}9 \text { days }^{1} \\
14 \text { days } \\
25 \text { days }^{1} \\
28 \text { days }^{1} \\
36 \text { days }^{2}\end{array}$ & $\begin{array}{l}\text { diffuse } \\
\text { diffuse }^{+} \\
\text {diffuse }^{+} \\
\text {focal } \\
\text { absent }\end{array}$ & $\begin{array}{l}\text { good } \\
\text { good } \\
\text { good } \\
\text { good } \\
\text { good }\end{array}$ & lt. hemiparesis (14 days) \\
\hline $\begin{array}{l}9 \text { days } \\
15 \text { days }^{2} \\
28 \text { days }\end{array}$ & $\begin{array}{l}\text { diffuse } \\
\text { improved } \\
\text { focal }\end{array}$ & $\begin{array}{l}\text { poor } \\
\text { good } \\
\text { good }\end{array}$ & lt. hemiparesis ( 8 days) \\
\hline $\begin{array}{l}7 \text { days } \\
12 \text { days }\end{array}$ & $\begin{array}{l}\text { focal } \\
\text { focal }^{+}\end{array}$ & $\begin{array}{l}\text { good } \\
\text { poor }\end{array}$ & $\begin{array}{l}\text { lt. hemiparesis and cons. } \\
\text { deteriorated ( } 11 \text { days) }\end{array}$ \\
\hline $\begin{array}{l}7 \text { days } \\
63 \text { days }\end{array}$ & $\begin{array}{l}\text { present }^{3} \\
\text { absent }\end{array}$ & $\begin{array}{l}\text { good } \\
\text { good }\end{array}$ & $\begin{array}{l}\text { rt. hemiparesis and } \\
\text { aphasia ( } 9 \text { days) }\end{array}$ \\
\hline $\begin{array}{l}1 \text { day } \\
9 \text { days }\end{array}$ & $\begin{array}{l}\text { absent } \\
\text { focal }\end{array}$ & $\begin{array}{l}\text { good } \\
\text { good }\end{array}$ & none \\
\hline $\begin{array}{l}1 \text { day } \\
9 \text { days }\end{array}$ & $\begin{array}{l}\text { absent } \\
\text { diffuse }\end{array}$ & $\begin{array}{l}\text { good } \\
\text { poor }\end{array}$ & $\begin{array}{l}\text { rt. hemiparesis and cons. } \\
\text { deteriorated ( } 7 \text { days) }\end{array}$ \\
\hline $\begin{array}{l}0 \text { day } \\
7 \text { days }\end{array}$ & $\begin{array}{l}\text { absent } \\
\text { focal }\end{array}$ & $\begin{array}{l}\text { good } \\
\text { good }\end{array}$ & none \\
\hline $\begin{array}{l}2 \text { days } \\
9 \text { days }\end{array}$ & $\begin{array}{l}\text { absent } \\
\text { focal }\end{array}$ & $\begin{array}{l}\text { good } \\
\text { good }\end{array}$ & none \\
\hline
\end{tabular}

+Improved; "worsened. 'Vertebral angiography was not performed. ${ }^{2}$ Only right carotid angiography was performed. ${ }^{3} \mathrm{Ac}-$ curate information was not obtained, as angiography was first performed in another hospital. ${ }^{4}$ Only left carotid angiography was performed.

こし，結果的にはVSの自然経過よりもさらに悪化させた と考えられた。

\section{N 結 果}

1. 血管閉塞と AN の発生部位および治療法

主幹動脈閉塞部位の内訳は, IC 5 例, $\mathrm{M}_{1} 3$ 例，総頸動 脈(CC) 1 例であった。破裂 AN の部位は, IC 4 例, ACo 3 例, PC-PCo 分岐部 2 例であった。 また, 非破裂 ANを 6 例に 7 個認めた。AN の発生部位は 6 例(11個)では主な 側副血行路上であり，他の 1 例(〈症例 6〉) む $\mathrm{MC}$ 閉塞例 で, 閉塞部直前の IC-PCo 分岐部に AN を認めた。 AN の 部位と血管閉塞部位の分布を Fig. 4 に, 主要な側副血行
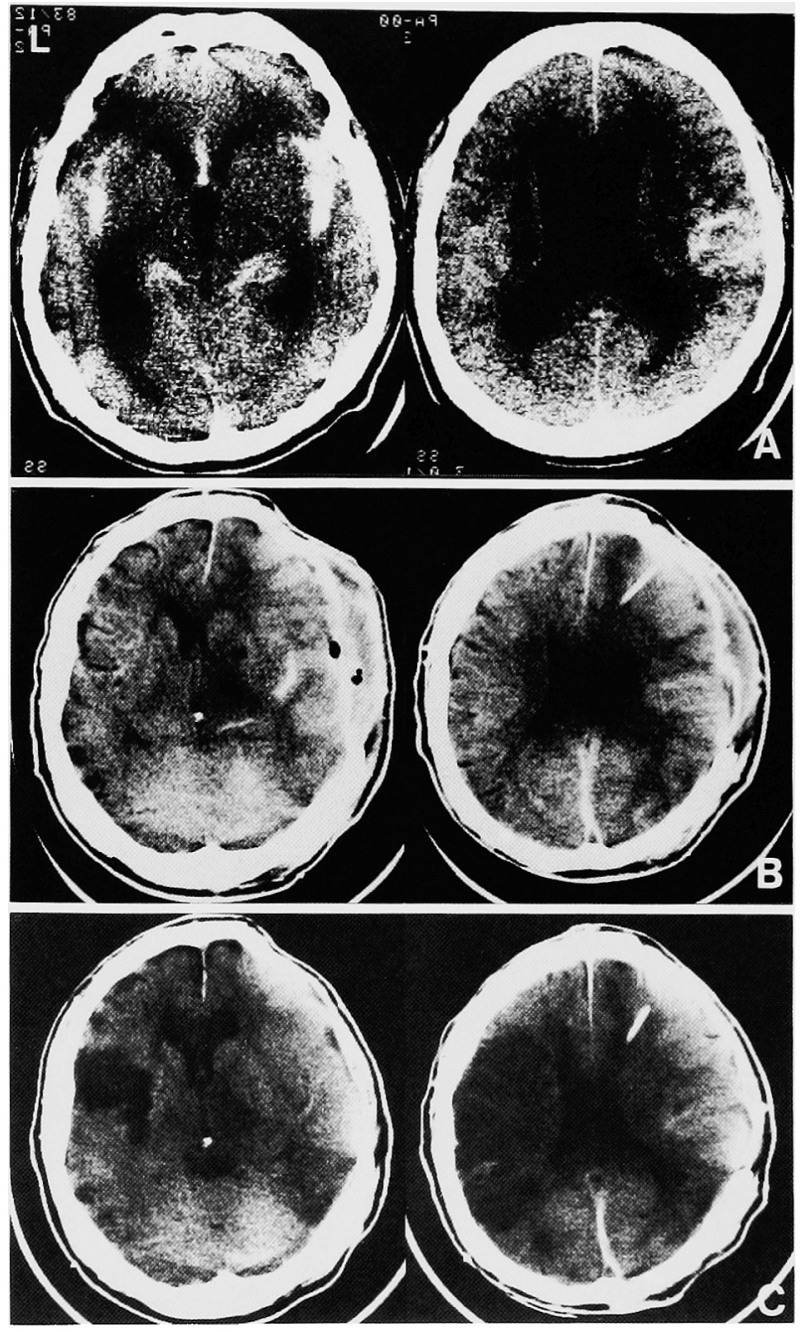

Fig. 1 Case 7. A: On admission, computed tomography (CT) showed diffuse subarachnoid bleeding, which was severer on the right side, and ventricular enlargement. B: CT scan obtained on day 4 demonstrated an epidural mass and midline shift. C: CT scan taken 11 days after onset showed low-density areas in the left temporoparietal and bilateral anterior periventricular regions.

路をTable 1 に示した。また，今回検討した 9 例中 3 例 (〈症例 2,3，6〉) では血管閉塞部位に側副血行路としての 一側性のモヤモヤ現象を認めた. Fig. 5 にその脳血管撮影 を示す

ANへのアプローチは, 〈症例 1, 3, 5〉ではfrontobasal lateral approach, 〈症例 9〉では anterior interhemispheric approach, 他 5 例では trans-sylvian approach で行った. 4 例 (〈症例 1, 3, 4,8〉)では AN 手術に引き続いて, 〈症例 5〉で は慢性期に ST-MC ハイパスを施行，また 3 例では外減 

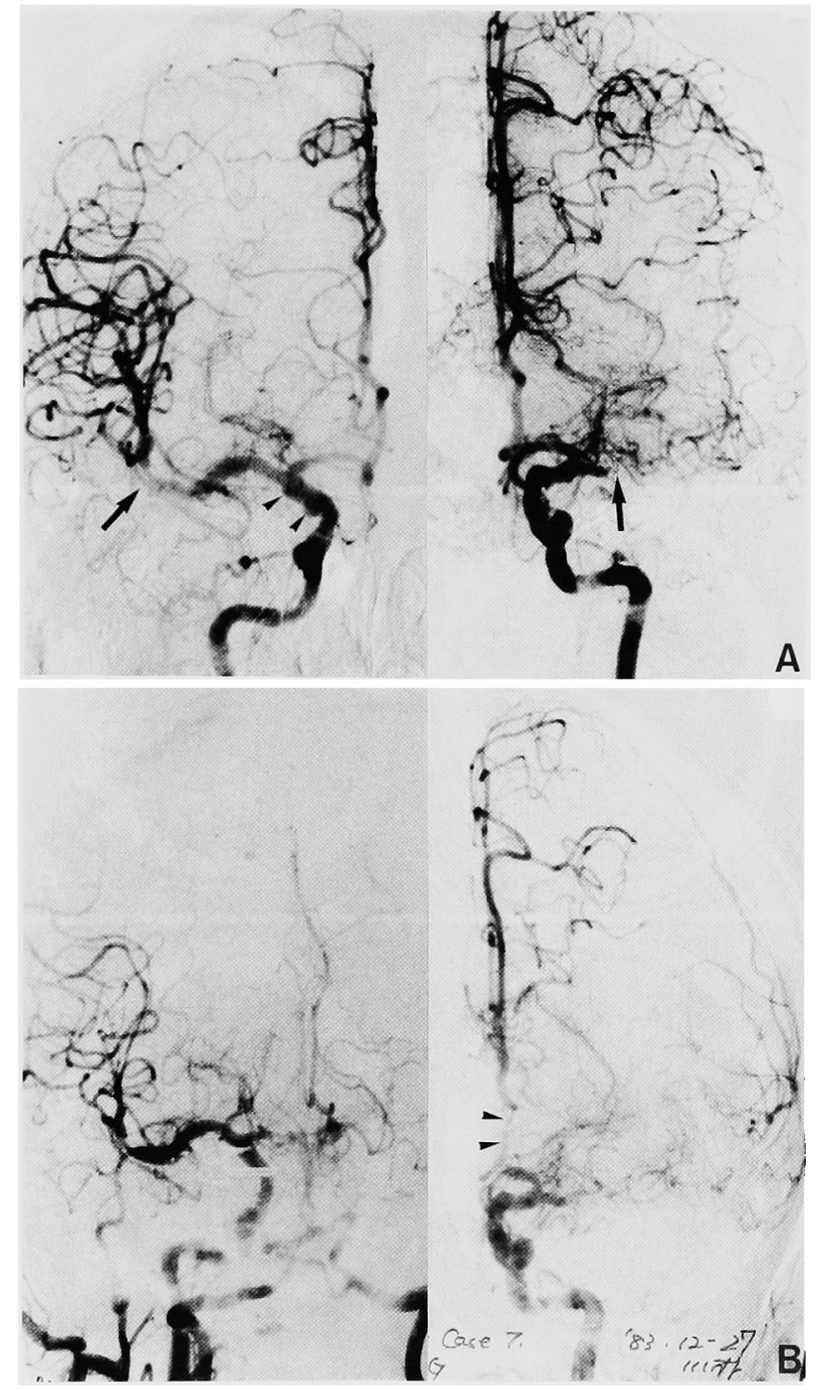

Fig. 2 Case 7. A: Preoperative bilateral carotid angiograms (CAG), anteroposterior (AP) view. The right CAG (left) demonstrates two internal carotid artery (IC) aneurysms (arrowheads) and about 50\% stenosis at the right horizontal portion of middle cerebral artery $\left(\mathbf{M}_{1}\right)$ (arrow). The left CAG (right) displays left $\mathrm{M}_{1}$ occlusion (arrow). Blood flow in the region of the left middle cerebral artery (MC) is mainly through leptomeningeal anastomoses from the left anterior cerebral artery (AC). B: Postoperative bilateral retrograde brachial angiograms (left) and left CAG (right), AP view. Severe vasospasm in the right $A C$ is evident. There are also localized vasospasm in the left AC (arrowheads), and a significant reduction in collateral flow to the left MC.

圧術を $\mathrm{AN}$ 根治術と同時に施行した. SAH 後水頭症に対

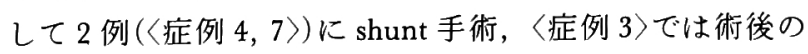
subdural effusion に対し subduro-peritoneal shunt を施行し

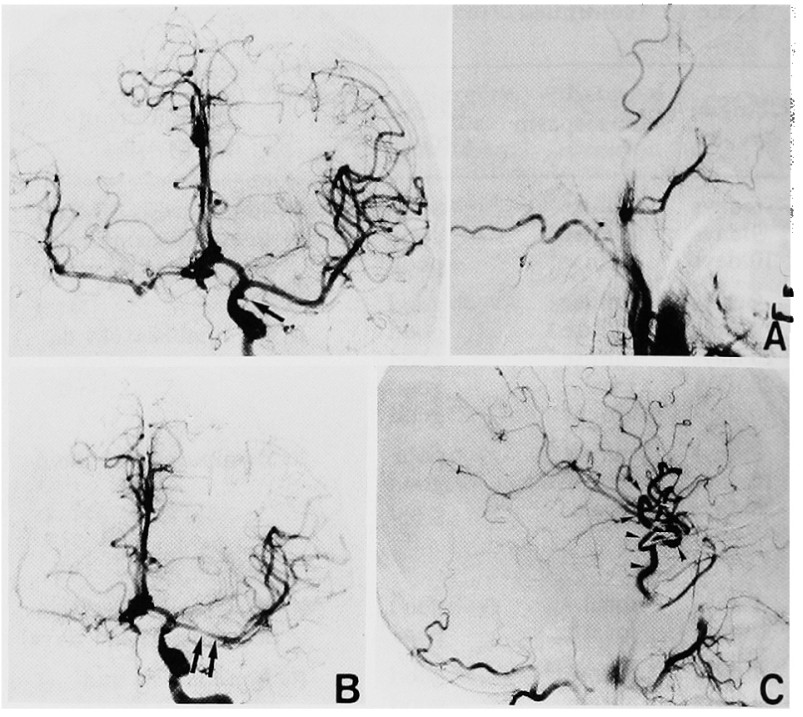

Fig. 3 Case 8. A: AP view of left CAG (left) and lateral view of right CAG (right) obtained on admission. The right IC is occluded in the neck. There is excellent filling of the right $\mathrm{MC}$ and $\mathrm{AC}$ through the anterior communicating artery (ACo). A ruptured left IC aneurysm is seen (arrow), but a non-ruptured ACo aneurysm is not well visualized here. B: AP view of left CAG performed 7 days after the onset of subarachnoid hemorrhage ( $\mathrm{SAH}$ ). Focal vasospasm is noted (arrows), as well as a marked reduction in collateral flow from left IC system to the right MC. C: Lateral view of right CAG obtained 43 days after the onset of SAH. The right superficial temporal arteries (arrowheads) are significantly dilated and excellent filling of the right MC via the anastomoses is demonstrated.

た。 また，後期の〈症例 6〜9〉ではアルブミンなどの投与 や輸血輸液による hypervolemic therapy を術後早期より 行った.

\section{2. 転帰 (Table 2)}

転帰良好群：9例中 4 例の転帰は全快であった。これら 4 例中 3 例の手術時期は SAH 発症後48時間以内の急性期 であった．他 1 例(左 $\mathrm{M}_{1}$ 閉塞を伴う〈症例 2〉)ではVSに 上る右半球の局所症状 (左不全片麻㾝) を SAH 後14日目に 認めたが、約 1 週間の経過で同症状は改善 消失し， SAH 後35日目に AN 根治術を施行した。

転帰不良群：9 例中 5 例は転帰不良で， 2 例は一部要介 助, 2 例は全介助, 他 1 例は死亡した。これら 5 例中 4 例 ではSAH 後 9 26日目に AN 根治術を行っていた。転帰 不良となった原因として，5例全例で症候性 VS が関与し ていた. 5ち2 例ではそれぞれSAH 後 9 日目および10日 目の VS が存在する時期に AN 根治術が行われ，術後に脳 

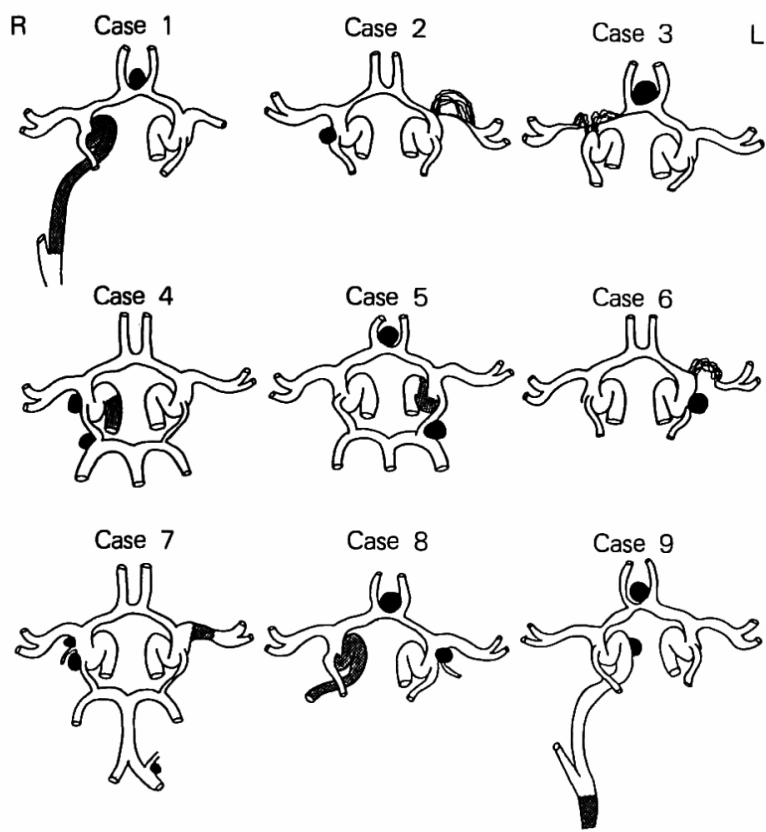

Fig. 4 Schematic illustrations of the aneurysms (black areas) and the arterial occlusions (shaded areas) in the nine patients.

浮腫またはVS の増悪をみており，手術時期が不適当であ ったと考えられた。 また，〈症例 1〉では術中に主要側副血 行路である ACo に一時血行遮断を行っており，手術自体 にも問題があったと言えた。これら 5 例では SAH 後 3〜 11日目にVSによる神経徵候を認めたが，そのうちく症例 5)を除く 4 例ではSAH 後 6〜12日目に側副血行が不良な 領域を認めた。これら 5 例全例で閉塞側とVSによる神経 改候の出現した半球側とが一致しており，VSにより閉塞 側の脳虚血が顕在化した場合には重度の神経症状を残して いた。

\section{3. $\mathbf{C B F}$}

Table 3 KCBF を検討した 3 例の結果をまとめた。半 球性乏血を認めた症例はなかったが，〈症例 5〉では右半球 に比べ左半球の CBF が著明に低々, 局所的にも $38 \mathrm{ml}$ $100 \mathrm{~g} / \mathrm{min}$ 未満の乏血領域を認めたため, バイパス術を適 応した．本例ではバイパス術後に CBF の左右差は改善さ れ, 当院退院後 4 年目の現在, 軽度の右不全片麻痺拉よび 運動性失語を残するのの, 介助不要で有為な自立生活を送 っている.〈症例 8〉ではSAH 後 7 日目に左半球に比べ右 半球の CBF が低値を示したが. 両半球とも正常値上限を 越えていた。
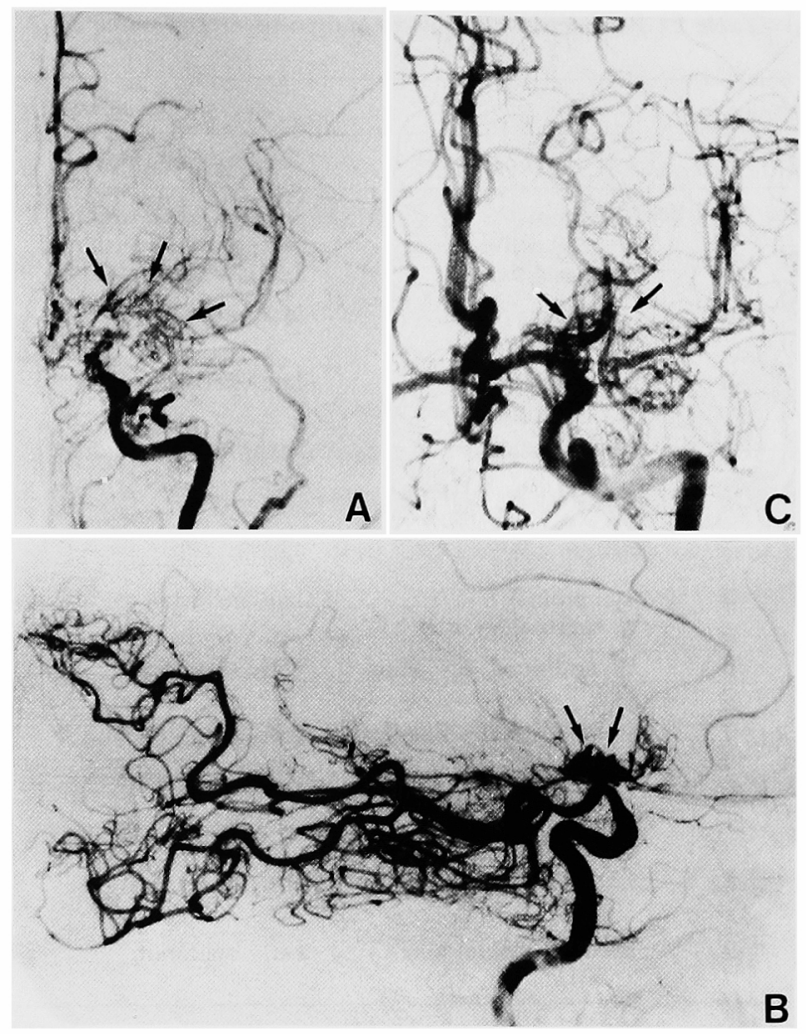

Fig. 5 Three patients with moyamoya phenomenon. Arrows indicate moyamoya vessels. A: Case 2 . A left CAG taken 14 days after the onset of SAH, AP view. B: Case 3. Lateral view of serial right $C A G$ performed 15 days after the onset of SAH, showing excellent filling of the right $\mathrm{MC}$ through leptomeningeal anastomoses from the right posterior cerebral artery. C: Case 6. Left CAG, AP view, obtained on admission.

\section{$\mathrm{V}$ 考察}

主幹動脈閉塞を伴った破裂 $\mathrm{AN}$ 症例の報告はしばしば 散見されるが，そのらち AN 根治術が施行された報告例 は，著者らが渉椫しえた範囲では Moyes ${ }^{8)}$ ．沼口ら ${ }^{9)}$ ，鶴 田 ${ }^{16)}$ ，今泉ら ${ }^{4)}$. Tasker ${ }^{(4)}$ の各 1 例扰よび熊谷ら ${ }^{6)}$ の(症 例 2〉, 片岡 $5^{5)} の\left\langle\right.$ 症例 1〉, さらに Matsuda $5^{7)} の\langle$ 症例 6〉を除く他 6 例，計13例であった。これらの報告では ANの成因と側副血行がもたらす hemodynamic stress を関 連付けた考察が主眼となっており，本症の治療に対して は, 今泉ら ${ }^{4)}$ が手術時の体血圧下降に注意し, $\mathrm{CBF}$ の保持 に留意すべきであると述べているにすぎない Matsuda ら ${ }^{7)}$ の報告の〈症例 1〉では, AN 根治とともに閉塞側半球 への側副血行を改善する目的で encephalomyosynangiosis が施行されている。しかし，上記のいずれの報告において 
Table 2 Perioperative problems and postoperative outcome

\begin{tabular}{|c|c|c|c|c|c|}
\hline \multirow{2}{*}{$\begin{array}{l}\text { Case } \\
\text { No. }\end{array}$} & \multicolumn{3}{|c|}{ Problems } & \multirow{2}{*}{$\begin{array}{l}\text { Outcome at } \\
\text { discharge }\end{array}$} & \multirow{2}{*}{$\begin{array}{l}\text { Status at } \\
\text { follow-up } \\
\text { (time) }\end{array}$} \\
\hline & Preoperative & Operative & Postoperative & & \\
\hline 1 & $\begin{array}{l}\text { symptom-VS } \\
\rightarrow \text { progressive neuro- } \\
\text { logical deficit }\end{array}$ & $\begin{array}{l}\text { inappropriate timing, } \\
\text { temporary occlusion of } \\
\mathrm{ACo}^{* *}(9 \text { minutes })\end{array}$ & $\begin{array}{l}\text { brain swelling progressed } \\
\rightarrow \text { additional external decom- } \\
\text { pression }\end{array}$ & $\begin{array}{c}\text { died }(12 \\
\text { days }\end{array}$ & - \\
\hline 2 & $\underset{\substack{\text { symptom-VS } \\
\rightarrow \text { recovered }}}{\text { s. }}$ & late operation & none & $\begin{array}{l}\text { fully } \\
\text { recovered }\end{array}$ & unknown \\
\hline 3 & $\underset{(\rightarrow \text { permanent deficit })}{\text { symptom-VS }}$ & late operation & $\begin{array}{l}\text { rt. subdural effusion } \\
\rightarrow \text { recovered after SP shunt }\end{array}$ & $\begin{array}{l}\text { partially } \\
\text { dependent }\end{array}$ & $\begin{array}{l}\text { died of cancer } \\
\quad(7 \text { years })\end{array}$ \\
\hline 4 & nonsymptom-VS & inappropriate timing & $\begin{array}{l}\text { symptom-VS, brain swelling, } \\
\text { hemorrhagic infarction } \\
\rightarrow \text { external decompression } \\
\rightarrow \text { cons. disturbance and lt. } \\
\text { hemiparesis persisted }\end{array}$ & $\begin{array}{l}\text { fully } \\
\text { dependent }\end{array}$ & unknown \\
\hline 5 & $\underset{(\rightarrow \text { permanent deficit })}{\text { symptom-VS }}$ & late operation & $\begin{array}{l}\text { lt. ST-MC bypass and cranio- } \\
\left.\text { plasty ( } 89 \text { days }{ }^{*}\right)\end{array}$ & $\begin{array}{l}\text { partially } \\
\text { dependent }\end{array}$ & $\begin{array}{l}\text { self-reliant ( } \\
\text { years) }\end{array}$ \\
\hline 6 & no additional problems & early operation & none & $\begin{array}{l}\text { fully } \\
\text { recovered }\end{array}$ & $\begin{array}{c}\text { unchanged }(2 \\
\text { years })\end{array}$ \\
\hline 7 & no additional problems & early operation & $\begin{array}{l}\text { swollen temporal muscle } \\
\rightarrow \text { resection, } \\
\text { symptom-VS } \\
\rightarrow \text { cons. disturbance and rt. } \\
\text { hemiparesis persisted }\end{array}$ & $\begin{array}{l}\text { fully } \\
\text { dependent }\end{array}$ & $\begin{array}{l}\text { unchanged ( } 2 \\
\text { years) }\end{array}$ \\
\hline 8 & no additional problems & early operation & none & $\begin{array}{l}\text { fully } \\
\text { recovered }\end{array}$ & $\begin{array}{l}\text { unchanged ( } 5 \\
\text { months) }\end{array}$ \\
\hline 9 & $\begin{array}{l}\text { small lt. frontal lobe } \\
\text { ICH }\end{array}$ & early operation & $\begin{array}{l}\text { disorientation as a frontal } \\
\text { sign } \rightarrow \text { recovered }\end{array}$ & $\begin{array}{l}\text { fully } \\
\text { recovered }\end{array}$ & $\begin{array}{l}\text { unchanged ( } 5 \\
\text { months) }\end{array}$ \\
\hline
\end{tabular}

*Interval from the onset of SAH; ** main collateral route. ICH indicates intracerebral hematoma; SP, subduro-peritoneal; symptom-VS, symptomatic vasospasm.

Table 3 Sequential measurement of cerebral blood flow (CBF) in three patients

\begin{tabular}{|c|c|c|c|c|c|c|c|c|}
\hline \multirow{2}{*}{$\begin{array}{l}\text { Case } \\
\text { No. }\end{array}$} & \multirow{2}{*}{$\begin{array}{l}\text { Interval } \\
\text { from SAH }\end{array}$} & \multicolumn{3}{|c|}{ Mean hemispheric CBF $(\mathrm{m} / / 100 \mathrm{~g} / \mathrm{min})$} & \multirow{2}{*}{$\begin{array}{l}\text { Method and normal } \\
\text { range of CBF* } \\
(\mathrm{m} l / 100 \mathrm{~g} / \mathrm{min})\end{array}$} & \multicolumn{2}{|c|}{ Blood } & \multirow{2}{*}{$\underset{(\mathrm{mmHg})}{\mathrm{Max} / \mathrm{min} B P}$} \\
\hline & & Rt. & & Lt. & & $\mathrm{PaO}_{2}(\mathrm{mmHg})$ & $\mathrm{PaCO}_{2}(\mathrm{mmHg})$ & \\
\hline 5 & $\begin{array}{l}71 \text { days } \\
112 \text { days }\end{array}$ & $\begin{array}{l}56 \\
46\end{array}$ & $\gg$ & $\begin{array}{l}45 \\
42\end{array}$ & $\begin{array}{l}{ }^{133} \mathrm{Xe} \text { inhalation; } \\
38-65\end{array}$ & $\begin{array}{r}108.6 \\
83.7\end{array}$ & $\begin{array}{l}46.1 \\
43.6\end{array}$ & $\begin{array}{l}116 / 70 \\
120 / 76\end{array}$ \\
\hline 6 & $\begin{array}{r}1 \text { day }^{* *} \\
9 \text { days } \\
14 \text { days } \\
22 \text { days }\end{array}$ & $\begin{array}{l}60 \\
59 \\
49 \\
53\end{array}$ & & $\begin{array}{l}62 \\
56 \\
48 \\
53\end{array}$ & $\begin{array}{l}{ }^{133} \mathrm{Xe} \text { IV injection; } \\
40-65\end{array}$ & $\begin{array}{r}101.5 \\
85.2 \\
92.1 \\
98.1\end{array}$ & $\begin{array}{l}38.1 \\
40.7 \\
39.3 \\
40.9\end{array}$ & $\begin{array}{l}110 / 74 \\
140 / 90 \\
110 / 70 \\
110 / 78\end{array}$ \\
\hline 8 & $\begin{array}{r}2 \text { days } \\
7 \text { days } \\
14 \text { days } \\
42 \text { days } \\
71 \text { days }\end{array}$ & $\begin{array}{r}44 \\
\uparrow 71 \\
55 \\
54 \\
44\end{array}$ & $<$ & $\begin{array}{r}44 \\
\uparrow 78 \\
54 \\
54 \\
45\end{array}$ & $\begin{array}{l}{ }^{133} \mathrm{Xe} \text { IV injection; } \\
40-65\end{array}$ & $\begin{array}{r}74.0 \\
\downarrow 58.0 \\
80.7 \\
91.1 \\
93.2\end{array}$ & $\begin{array}{r}38.3 \\
\uparrow 52.7 \\
45.1 \\
47.3 \\
47.9\end{array}$ & $\begin{array}{c}140 / 70 \\
\uparrow 174 / 110 \\
134 / 70 \\
112 / 70 \\
134 / 70\end{array}$ \\
\hline
\end{tabular}

${ }^{*}$ Normal range of CBF: $-2 \mathrm{SD}^{-}+2 \mathrm{SD} ;{ }^{* *}$ preoperative study. $\uparrow:$ increased, $\downarrow:$ decreased, $<:$ unequal, $\gg:$ markedly unequal. BP indicates arterial blood pressure; IV, intravenous.

む，主に本症の治療法について検討した報告は見当らな い，そこで，今回は，本症の特に外科的治療法を明らかと する目的で，佐山ら ${ }^{10)}$ がすでに報告した 2 例に 7 症例な加 えて手術成績を検討した。

SAH 後, 脳循環代謝はVS, クモ膜下血腫 ${ }^{3)}$ 、頭蓋内圧 (ICP) 亢進 ${ }^{1)}$ 。水頭症 ${ }^{17)}$, hypovolemia ${ }^{11)}$ ，手術侵襲といっ
た種々の要因で障害される。主幹動脈閉塞を伴ら場合に は，さらに側副血行も障害されることが予想される。今回 の症例ではいずれも臨床的に虚血性脳血管障害の既往を認 めず，SAH 発症まで側副血行は良好であったと考兄られ だ、ところが，9 例中，転帰不良の 5 例では脳血管撮影で VSの存在が確認されており，それによって側副血行が障 
害され，主幹動脈の閉塞側とVSによる神経徵候の発現し た半球側とが一致していた。主幹動脈の閉塞側とVS 出現 側とが不一致であった 1 例では転帰良好であった。すなわ ち、SAH 発症まで潜在していた脳虚血がVSの出現とと もに顕在化した場合には転帰は不良であった。

田澤ら ${ }^{15)}$ は両側 $\mathrm{M}_{1}$ 閉塞を伴う破裂 $\mathrm{ACo}$ AN 症例で, AN 根治術を施行しえぬまま不良な転㷌をとった 1 例を報 告し, 本例では SAH 発症後 3 日以内にバイパス術と AN 根治術を行うべきであったと述べている. 今回の症例のら ち，早期手術を行い之た〈症例 7〉もまた，AN 根治ととも にバイパス術を施行しておれば脳虚血を軽隇できた可能性 があったと反省させられた，他方，早期手術で AN 根治 とともにバイパス術を施行したく症例 8〉では, 術後の脳血 管撮影でVSを認めたにもかかわらず，これによる症状の 悪化はみられず，バイパスが側副血行の維持に有効であっ た。本例では SAH 後 7 日目に CBF が正常上限を越兄た が，これは高炭酸血症，低酸素血症拈よび高血生状態によ るものと考えられた。しかし，〈症例 4〉のように，すでに VSが出現してからではAN 根治術およびバイパス術を行 らことが脳虚血，脳損傷をかえって増強させる可能性もあ り, この時期の手術は極力避けるべきである. 主幹動脈の 閉塞がない場合においても，VSが出現している時期には 脳虚血の増強を引き起こしやすく，この期間の手術は行ら べきではない19)ことを考劣ると当然の結果と言える.

これらより，主幹動脈の閉塞を伴ら破裂 $\mathrm{AN}$ 症例にお いては, SAH が高度で，VSにより側副血行路からの血流 障害が予想される場合には，急性期に閉塞側の予防的パ パス術を行らのが妥当と考えられた。この際，現在著者ら が破裂 AN急性期症例に対して行っている以下の治療 法 ${ }^{18)}$ 。才なわら脳脊髄液ドレナージにより水頭症と ICP をコントロールする, 術後早期から循環血液量を保ち,

VSが出現した場合には血圧を上昇させたり心拍出量を增 加させるといった脳灌流压を保つ治療法を併用することる 必要である.

AN の成因に hemodynamic stress の関与することは従来 より指摘されている。考察の最初にも述べたが，主幹動脈 の閉塞に ANを合併した場合，多くの症例で閉塞に伴ら 血行動態の変化が AN の増大, 破裂に影響していると指 摘されている．今回の症例でも 9 例中 6 例では側副血行路 上, 他の 1 例では閉塞部の直前に $\mathrm{AN}$ が存在しており。 血行動態が AN の発育に大きく関与していると思われた。 また，9例中 6 例は多発性 AN 症例で，そのうち5例では ANは側副血行路上に存在しており，これを合せると側副 血行路上の AN は総計16個中の11個 (69\%) に相当した。 Somach ら ${ }^{21}$ は頸動脈結禁術を施行した20例中 2 例におい
て，術後 7〜8 年目に新たな AN の出現を認めたと報告し ている.〈症例 9〉では10年前に右 IC (cavernous portion) AN に対し右 $\mathrm{CC}$ 結惄術が施行されているが，この人為的 な血行動態の变化によりACoにかかる hemodynamic stress が増大し，10年前に存在した ACo AN が増大一(再) 破裂したと考光られた。これらの結果は，ANの形成，增 大，破裂に hemodynamic stressが関与していることを支 持するものであった。

また，今回の 9 例中 3 例にモヤモヤ現象13)を認めた。こ れら 3 例のモヤモヤ血管網は，いわゆるモヤモヤ病のそれ と異なり，脳血管撮影側面像 (Fig. 5)で明らかなよらに， トルコ鞍上部に一塊となって観察され，府川らが報告し た剖検例での所見と一致していた。このよらなモヤモヤ現 象は，主幹動脈狭窄 閉塞の過程で長期間を要して発達し た側副血行路と推測できた，比較的珍しい病態であるモヤ モヤ血管網を今回 9 例中 3 例といら高率に認めたことは, このような血管病変が血行動態に变化をもたらし，ANの 発育，増大，破裂に関与していることを示すものと思われ た.モヤモヤ現象の成因と AN 発生との因果関保は明ら かではないが，特異な所見と考え，追加した。

\section{V ま とめ}

主幹動脈閉塞を伴弓破裂 $\mathrm{AN}$ 症例に対する適切な治療 法を明らかとする目的で, 手術例 9 例の治療成績扎よび転 帰を左右した因子につき検討した。 その結果，本症では可 及的早期に破裂 AN 根治術を行らとともに，VSによる閉 塞側脳虚血の顕在化を予防する目的でバイパス術も適応す ベきと考えられた。また，主幹動脈閉塞による血行動態の 変化のANに対する影響などについても考察した。

\section{文献}

1) Fein JM: Cerebral energy metabolism after subarachnoid hemorrhage. Stroke 6: 1-8, 1975

2）府川修，相原坦道，若狭治毅：モヤモヤ様血管網を伴。 た特発性中大脳動脈閉塞症一第 2 報 1 剖検例の検討一. 脳 神外科 10:1303-1310,1982

3) Gado MH: Effects of subarachnoid hemorrhage on cerebral blood volume, blood flow, and oxygen utilization in humans. $J$ Neurosurg 46: 446-453, 1977

4）今泉茂樯, 長嶺義秀, 中村信之, 片倉隆一, 樋口紘大 動脈炎症候群に伴った前交通動脈溜の1 手術治験例. 脳神外 科 10: 449-455, 1982

5）片岡和夫, 種子田護：両側頸動脈閉塞に合併した脳動脈瘤. Neurol Med Chir (Tokyo) 22: 744-750, 1982

6）熊谷頼佳，杉山弘行，名和田宏，伊関洋，馬場元毅，太 田秀一，代瓶博史，谷島健生，高倉公朋，佐野圭司，斎藤 勇：脳動脈瘤を合併した脈なし病の 2 例。脳神外科 $9: 611$ 
615,1981

7) Matsuda M, Handa J, Saito A, Matsuda I, Kamijyo Y: Ruptured cerebral aneurysms associated with arterial occlusion. Surg Neurol 20: 4-12, 1983

8) Moyes PD: Basilar aneurysm associated with agenesis of the left internal carotid artery. Case report. J Neurosurg 30: 608-611, 1969

9）沼口浩太郎, 新垣良浩, 内山元昭, 朝長正道, 石井 友 : 右内頸動脈形成不全を伴った前交通動脈瘤の1手術例. 䧢神 経 14: 716, 1974

10）佐山一郎，伊藤善太郎，中島健二，大田英則，鈴木明文， 小林恒三郎：内頸動脈閉塞を伴ら多発性脳動脈瘤の 2 例，脳 神外科 7: 797-804, 1979

11) Solomon RA, Post KD, McMurtry JG III: Depression of circulating blood volume in patients after subarachnoid hemorrhage: Implications for the management of symptomatic vasospasm. Neutosurgery 15: 354-361, 1984

12) Somach FM, Shenkin HA: Angiographic end-results of carotid ligation in the treatment of carotid aneurysm. $J$ Neurosurg 24: 966 974,1966

13）竹内一夫：Moyamoya 現象と moyamoya 病。脳と神 30 : 1183-1191，1978

14) Tasker RR: Ruptured berry aneurysm of the anterior ethmoidal artery associated with bilateral spontaneous internal carotid artery occlusion in the neck. J Neurosurg 59: 687-691, 1983

15）田澤俊明，水上公宏，富樫 修，兵頭明夫，江口孝：両 側中大脳動脈閉塞症に合併した前交通動脈動脈篗の1例。 Neurol Med Chir (Tokyo) 23: 478-482, 1983

16）鶴田潤介, 宮崎䧸二：前交通動脈瘤をともなった一側内頙 動脈完全欠損の1例. 脳神外科 5:895-900, 1977

17) Weir $B$, Menon $D$, Overton $T$ : Regional cerebral blood flow in patients with aneurysms: Estimation by xenon 133 inhalation. Can J Neurol Sci 5: 301-305, 1978

18）安井信之，鈴木明文，大田英則，上山博康，川村伸悟：破 裂脳動脈溜急性期の治療之問題点. Neurol Med Chir (Tokyo) 24: 409-415, 1984

19) Yasui N, Suzuki A, Ohta H, Kamiyama H, Kawamura S: Treatment of ruptured intracranial aneurysms at the acute stage-operative timing and results, in Auer LM (ed): Timing of Aneurysm Surgery. Berlin, Walter de Gruyter, 1985, pp 97-105

[別刷請求先：干010 秋田市千秋久保田町6-10, 秋田県立脳血管 研究センター脳神経外科, 川村伸悟] 